"Mircea cel Batran" Naval Academy Scientific Bulletin, Volume XIX - 2016 - Issue 1

Published by "Mircea cel Batran" Naval Academy Press, Constanta, Romania // The journal is indexed in:

PROQUEST / DOAJ / DRJI / JOURNAL INDEX / I2OR / SCIENCE LIBRARY INDEX / Google Scholar / Crossref /

Academic Keys / ROAD Open Access / OAJI / Academic Resources / Scientific Indexing Services / SCIPIO

\title{
SOME FEATURES REGARDING THE DESIGN OF THE TRAINING PROGRAMS OF MILITARY TEACHING STAFF
}

\author{
Nelu CÎRNEANU ${ }^{1}$ \\ ${ }^{1}$ Col. associate professor Ph.d., engineer. Combat Units Training School „Mihai Viteazul” Piteşti
}

\begin{abstract}
The adjustment of military education and continuous training system to the real needs of the Romanian Armed Forces by providing quality vocational training programs recognized at national level or at the level of the Ministry of National Defense, requires creating a proficiency and motivated teaching staff for professional development in the domain of military education, by integrating it into a coherent system of continuously training psycho-pedagogy and methodical.

The writing presents the aims and objectives of the three training programs (Trainer, Master trainer and Evaluator of professional competences) which can be set up into the Romanian Armed Forces education and training system.
\end{abstract}

Keywords: education and training, evaluator of professional competences, trainer, military training system, master instructor, occupational standards.

\section{THE NEED FOR TRAINING PROGRAMS OF MILITARY TEACHING STAFF}

Within the process of transformation and modernization of the system of military initial and continuing training of teaching staff is one of the military's top priorities. Improving the skills of persons with attributions in the field of education and vocational training involves:

- development of a initial and continuing training system of teaching staff, leadership, guidance and control of military education;

- professionalization of teaching and managerial career in the military education system by obtaining degrees in teaching through participation in the undergraduate masters and doctoral studies in the field of educational management;

-linking of training stages from didactics career with educational standards and developments in military career;

- development of modern institutional structures in order to optimize the initial training activities and continuous training improvement for the military teaching staff;

-recruitment, integration and retention in the teaching career of graduates of higher education institutions of military and civil with outstanding results, as well as specialists in fields of interest to the Romanian Armed Forces;

-exchange the best practices with similar educational institutions in the country and abroad;

-exploitation in the educational and training process of military personnel's experience taking part in exercises, assignments and military action, carried out together with foreign partners on the national territory or in different theatres of operations.
Regarding to those matters, at the National Defense Ministry level, it is necessary the elaboration of a policy for initial and continuous training of teachers staff through military training programs for occupations: Trainer, Master trainer and Evaluator of professional competences.

\section{THE AIMS AND OBJECTIVES OF THE} TRAINING PROGRAMS FOR MILITARY TEACHING STAFF

The training program for "Trainer" occupation code COR 241205

Aim: Skills/ competences acquisition by the responsible personnel with training and learning in military continuing education and training system, necessary for designing, conducting, evaluating and revising of theoretical and practical activities and/or training and skills development programs carried on by the specialized institutions or in the workplace.

Training program's objectives

1. Development of basic skills of designing training programs based on continuing training adults legislation, on occupational standards, on learner characteristics and on the real training needs of the Romanian Armed Forces.

2. The development of core competencies for effective implementation of methods and techniques of specific military education training, using effectively and flexibly both individual learning and group methods, while encouraging teamwork, personal reflection of participants in training, formation, shaping attitudes, skills development and responsibility-general autonomy, the ability of communication and developing the skills of lifelong learning.

3. Develop basic skills needed for the effective set up of training programs, depending on the specifics of the program and the participants, as 


\begin{abstract}
"Mircea cel Batran" Naval Academy Scientific Bulletin, Volume XIX - 2016 - Issue 1
Published by "Mircea cel Batran" Naval Academy Press, Constanta, Romania /I The journal is indexed in: PROQUEST / DOAJ / DRJI / JOURNAL INDEX / I2OR / SCIENCE LIBRARY INDEX / Google Scholar / Crossref /

Academic Keys / ROAD Open Access / OAJI / Academic Resources / Scientific Indexing Services / SCIPIO
\end{abstract}

well as in accordance with the principles of adult education, legal provisions and the human and non human available resources.

4. Development of basic skills necessary to perform training programs with a high level of quality compatible with the training requirements of European and Euro-Atlantic educational systems.

5. Development of the basic skills necessary for the evaluation of participants in training, and of their own benefits as trainer and training programs, based on principles, systems, procedures, criteria and indicators, management and quality assurance recognized specific training activities for the staff of the Romanian Army.

The training program for "Master trainer" occupation - code COR 235907.

Aim: The acquisition of skills by the staff responsible for education and training which carries out activities with practical-applicative character in military training through specific activities, to develop cognitive skills, practical, communication, psychomotor and aesthetic so that participants become self-motivated individuals, flexible, professional-oriented in order to warm to a high level of specialization, developed in specialized institutions or in the workplace.

Training program's objectives:

1. Development of basic skills on the enforcement of environmental, health and safety and emergency situations applicable to specific practical activities of the educational process.

2. Development of basic skills for the design of practical training activities based on laws related to the continuous training of adults, on occupational standards, on graduate characteristics and on the real training needs of the Romanian Armed Forces.

3. Development of basic skills regarding ensuring the management of practical training process by conducting a efficient set up of practical activities according with program and students feature and also with grownups education principles, according with legal stipulation and with available human and non human resources.

4. Development of basic skills necessary for evaluation of students regarding practical training activities also evaluation of its own work as a trainer based on the principles, procedures and indicators of quality management specific to training domain of Romanian Armed Forces personnel.

5. Development and improvement of skills relating to ensure the functionality and specific equipment machinery workshops/laboratories work required effective organization of practical training activities on the basis of the normative acts in force at national level and the Romanian Army

6. Development of basic skills regarding TIC integration in training, able to select the specific equipments and software resources applicable in training process.

7. Development of basic skills necessary for advising the trainers for their future personal and professional growth being able to project themselves their own way of professional training and carrier progress .

The training program for "Evaluator of professional competences" occupation - code COR 242405.

Aim: Skills acquisition by the responsible personnel for training and learning from military education and training system, needed to carry out the processes of evaluation of professional skills of military and civilian personnel, with a view to their certification.

Training program's objectives:

1. Development of basic skills on the enforcement of environmental, health and safety and emergency situations applicable to specific practical activities of the educational process.

2. Development of basic skills adult education, communication in adult training and assessment skills, creative problem solving specific problems of vocational training of adults, as well as for the development of professional counselors and career evolution.

3. Development of basic skills regarding the design, realization, evaluation and improvement of its activity on the basis of good practices in the field of assessment of skills promoted at national, European and international levels, in accordance with the requirements arising from the application of the principles of quality assurance.

4. Development of basic skills necessary to establish assessment tools, based on the identification critical aspects of competence according with methodology in force and occupational standards training, establish assessment methods, developing and reviewing the assessment tools.

5. Development of basic skills necessary to advise the candidate upon the evaluation process by training him for the evaluation process and informing him about his rights and obligations taking in consideration evaluator's ethics and also the methodologies and procedures in effect.

6. Development of basic skills regarding evaluation process setup, selecting applicable evaluation methods, establish conditions and preparing the activities of information gathering, preparing and reviewing the evaluation plan depending by identification of necessary 
"Mircea cel Batran" Naval Academy Scientific Bulletin, Volume XIX - 2016 - Issue 1

Published by "Mircea cel Batran" Naval Academy Press, Constanta, Romania // The journal is indexed in:

PROQUEST / DOAJ / DRJI / JOURNAL INDEX / I2OR / SCIENCE LIBRARY INDEX / Google Scholar / Crossref /

Academic Keys / ROAD Open Access / OAJI / Academic Resources / Scientific Indexing Services / SCIPIO

resources for evaluation process and by complying with the evaluation principles and with specific settlement regarding profession usage.

7. Development of the basic skills necessary to perform the evaluation based on the collection and recording of evidence of proficiency up to providing feedback to the candidate, based on the requirements of practicing the occupation.

8. Development of basic skills necessary for proof analysis of the competence gained by the candidate in assessment process, adopting the decision of competence, recording and reporting of the outcome of the assessment.

\section{CONCLUSIONS:}

1. The theme of the designed professional training program fits with nowadays requirements of quality assurance of education and training in European Union.

2. Training programs presented in this work provides for the teaching staff from military education system the necessary competences in order to develop other training programs for professional reconversion of defense personnel.

3. Military education and training system has the necessary resources to the set up and conduct initial and continuous training programs of teaching staff.

\section{BIBLIOGRAPHY}

[1] *** No. 1/2011, National Education Law, published in no. 18/2011 Romania Official Gazette;

[2] *** GD no. 1352/23.10.2010 in order to approve the Structure of occupations qualification in Romania basic group level, according to the International Standard Classification of Occupations, Romanian Official Gazette.

[3] *** User guide for occupational / vocational training standards in developing professional training programs, 2004, Bucharest, on www.anc.ro, accessed on 11 Oct. 2012;

[4] *** "Trainer" Occupational standard, COR code 242401, on www.anc.ro, accessed on 12 Oct. 2014;

[5] *** "Master trainer" Occupational standard, COR code 235907, on www.anc.ro, accessed on 14 Oct.

2014;

[6] *** "Evaluator of professional competences" Occupational standard, COR code 242405, on www.anc.ro, accessed on 16 Oct. 2014. 